\section{Visualization of the Distribution Pattern of Citrus Tristeza Virus in Leaves of Mexican Lime}

\author{
Youjian Lin \\ College of Plant Protection, Fujian Agriculture and Forestry University, \\ Fuzhou, Fujian 350002, China
}

\author{
Charles A. Powell ${ }^{1}$ \\ Indian River Research and Education Center, University of Florida, Fort \\ Pierce, FL 34945
}

Additional index words. citrus, whole-leaf-blot immunoassay, computer scanning imaging technique, CTV MAb 17G11, ELISA

\begin{abstract}
The distribution pattern of citrus tristeza virus (CTV) T-36 isolate in leaves of infected mexican lime [Citrus aurantifolia (Christm.) Swingle] plants was visualized using a whole-leaf-blot immunoassay (WLBIA) procedure in combination with a computer scanning imaging technique and CTV-specific monoclonal antibody 17G11 (CTV MAb 17G11). The distribution pattern of CTV T-36 in leaves varied with the age of the leaves and shoots of infected plants. In the young leaves, especially the about 5-day-old leaves and the completed expanded leaves, CTV T-36 was easily detected in most of the leaf veins, the main veins and the large and small primary veins. In the old leaves, CTV T-36 only was detected in the main veins, sometimes in a few of the large primary veins with weak signals, and seldom in the small primary veins. The distribution density and immunoassay reaction signals of CTV T-36 reacted to CTV MAb 17G11 in leaves from new shoots were much higher than that in leaves from old shoots. ELISA test results using leaves with different ages from different shoots of the same mexican lime plants infected with CTV T-36 supported the visualized-test results obtained by the WLBIA in combination with computer scanning imaging technique. This is the first reported visual analysis of the distribution pattern of CTV in leaves of infected citrus plants. The results indicate that the WLBIA in combination with computer scanning imaging technique is a useful tool for studying the distribution of plant viruses in leaves of virus-infected plants.
\end{abstract}

Citrus tristeza virus (CTV), a member of the genus Closterovirus with the largest genome among plant RNA viruses, occurs in most citrus producing regions, and is the most serious pathogen of citrus (Bar-Joseph et al., 1980; Ghorbel et al., 2001; Niblett et al., 2000). Control strategies for this virus focus on clean stock program, cross-protection, and breeding/engineering for resistance (Ghorbel et al., 2001; Lee et al., 1988; Mas and Pallas 1995; Niblett et al., 2000). Information regarding virus distribution in the plant is crucial to fully evaluate and implement these strategies. The distribution of CTV in infected citrus plants has been investigated by light and electron microscopy (Brlansky and Lee 1990; Garnsey et al., 1980; Kitajima and Costa 1968; Kitajima et al., 1974; Zhou et al., 2002), enzyme-linked immunosorbent assay (ELISA) (Bar-Joseph et al., 1980; Lee et al., 1988; Lin et al., 2000), in situ immunofluorescence technique (Brlansky and Lee 1988; Sasaki et al., 1980), dot-immunobinding assay (Rocha-Peña et al., 1991),

Received for publication 10 Jan. 2006. Accepted for publication $23 \mathrm{Feb} .2006$. The authors are grateful to S.M. Garnsey for providing CTV-specific polyclonal antibody 1212 and to Phyllis A. Rundell for her help in the lab. Florida Agriculture Experiment Station Journal Series: R-10841.

${ }^{1}$ Corresponding author: Charles A. Powell; email: capowell@mail.ifas.ufl.edu. reverse transcriptase-polymerase chain reaction (RT-PCR) (Huang et al., 2004; Hung et al., 2000; Sambade et al., 2000), direct tissue blot immunoassay (DTBIA) (Garnsey et al., 1993; Lin et al., 2000, 2006), and in situ immunoassay (ISIA)(Lin et al., 2002, 2000). The previous results indicated that CTV is located in the phloem tissues of leaf veins, stems, and petioles, and in the meristematic cells of young shoots (Brlansky and Lee 1988; Kitajima and Costa 1968; Kitajima et al., 1974; Sasaki et al., 1980; Schneider 1959; Schneider and Sasaki 1972; Zhou etal., 2002). Difference in distribution of CTV among the branches of an infected plant was also found. The distribution of CTV among branches of infected plants was even or

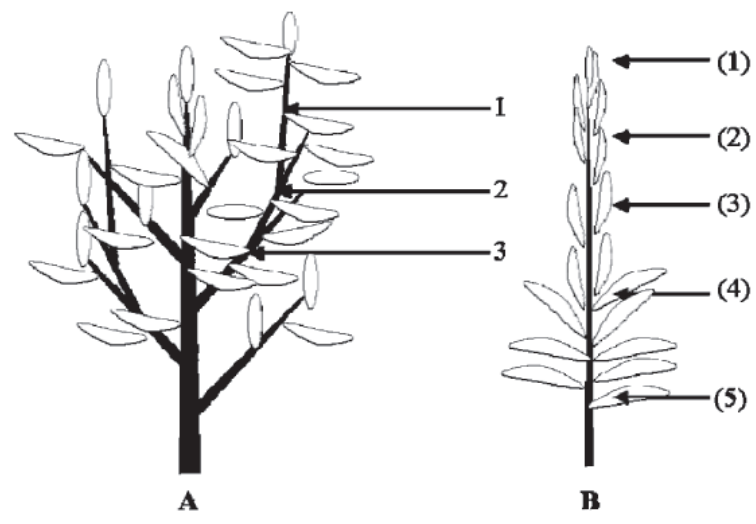

uneven depending on CTV strain, citrus variety, and the sampling season (Lee et al., 1988). None of these studies assess the distribution of CTV within leaves of different ages or leaves from shoots of different ages.

Polston et al. (1991) reported a whole-leafblot immunoassay using virus specific IgG to detect the coat proteins of viruses in leaves of infected plants. Mas and Pallas (1995) reported a nonisotopic tissue-printing hybridization technique to study the movement of plant viruses within leaves of infected plants. Labonne etal. (1997) reported an immunoprinting technique to detect the distribution of plum pox virus in leaves of infected Prunus. Their results indicated that both whole-leaf-blot immunoassay and whole-leaf-blot RNA-hybridization are useful tools to study the distribution pattern of viruses in leaves of infected plants. In this paper, we present the visible distribution pattern of CTVT-36 isolate in leaves of infected mexican lime plants using an improved whole-leaf-blot immunoassay in combination with computer scanning imaging technique.

\section{Materials and Methods}

Source of virus. CTV isolate T-36 in mexican lime [C. aurantifolia (Christm.) Swingle] was used in the experiments. T-36 isolate is a Florida decline-inducing isolate causing vein-clearing, stunting, and stem pitting on mexican lime and a decline reaction in sweet orange (Citrus sinensis L.) on sour orange (C. aurantium L.) rootstock (Lin et al., 2000; Rocha-Pena et al., 1991). Uninfected mexican lime plants were used as controls. The virus infections of mexican lime plants were obtained by grafting bud chips of T-36 isolate stock plants, which have been maintained in the research center quarantine greenhouse for $>30$ years, into mexican lime seedlings. The infected and uninfected mexican lime plants, confirmed by ELISA 3 months after inoculation and at 3 month intervals thereafter, were maintained in a quarantine greenhouse at the Indian River Research and Education Center, Fort Pierce, Fla., for 3 years before the initiating of these studies.

Sources of antibodies. CTV-specific monoclonal antibody MAb-17G11 generated and produced at the Indian River Research and

Fig. 1. Schematic representation of leaf sampling from shoots of mexican lime ((Citrus aurantifolia (Christm.) Swingle) plants that were infected or uninfected with Citrus tristeza virus (CTV) for visualization of the distribution pattern and difference in titer of CTV in leaves by whole-leaf-blot immunoassay procedure combined with computer scanning imaging technique and enzyme-linked-immunosorbent assay (ELISA). (A) Sampling ofleaves from different aged shoots of the plants: 1 ) new shoots, 2) medium-aged shoots, and 3) old shoots. (B) Sampling of leaves from the same new shoots: 1) youngest leaves, 2) 3-d-old leaves, 3) 5-d-oldleaves, 4) completely expanded leaves, and 5) mature leaves. 

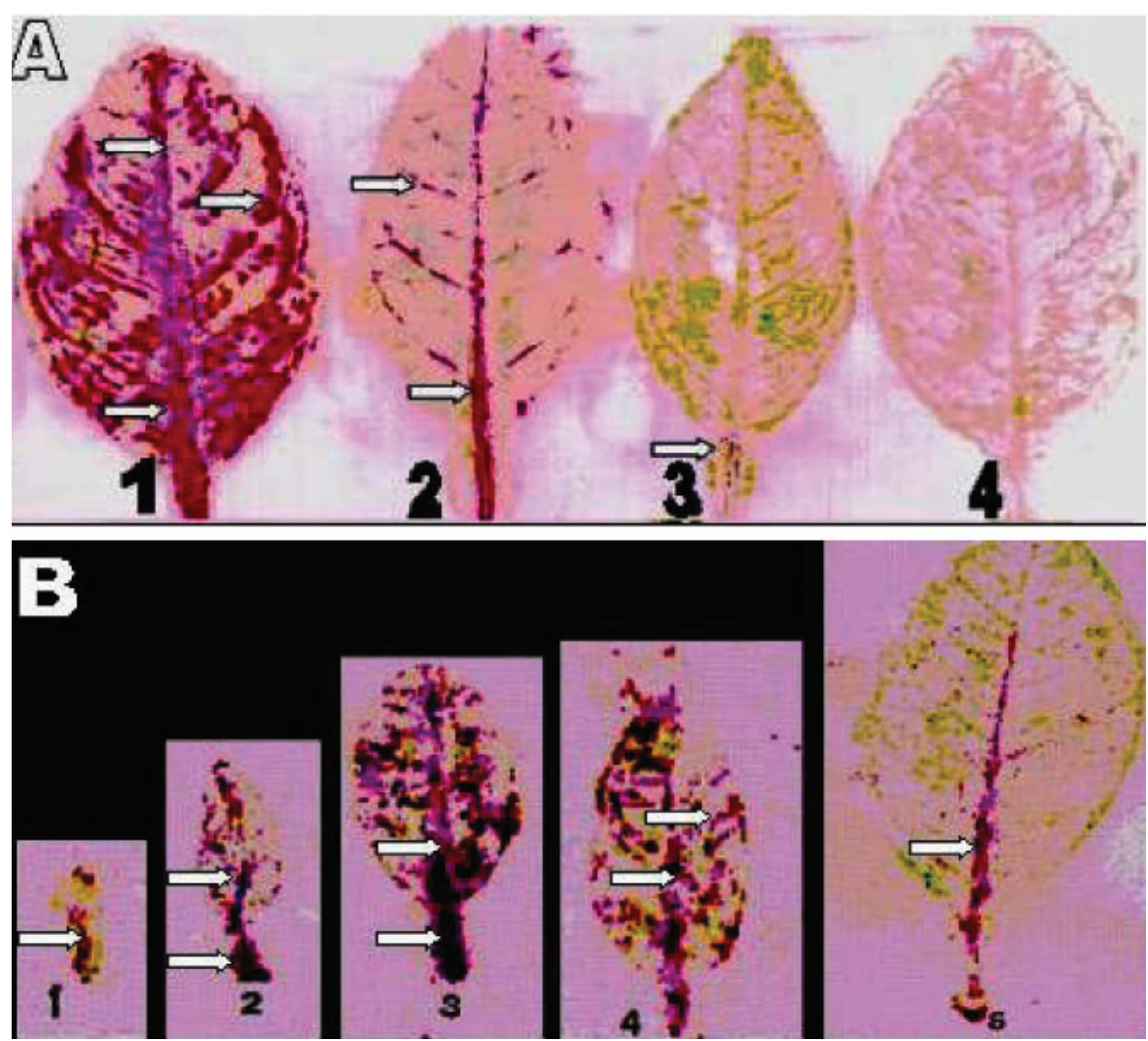

Fig. 2. Distribution pattern (marked by arrows) and difference in titer of Citrus tristeza virus (CTV) T-36 isolate in leaves of infected mexican lime (Citrus aurantifolia (Christm.) Swingle) plants visually detected by a whole-leaf-blot immunoassay procedure combined with computer-scanning-imaging technique. (A) Distribution pattern and difference in titer of CTV in leaves from different aged shoots. 1) CTV in a leaf from an infected new shoot; 2) CTV in a leaf from an infected medium-aged shoot; 3) CTV in a leaf from an infected old shoot; and 4) A leaf from an uninfected new shoot, showing no CTV was detected in the whole-leaf-blot. (B) Distribution pattern and difference in titer of CTV in leaves from the same infected new shoot. 1) CTV in youngest leaf; 2) CTV in 3-d-old leaf; 3) CTV in 5-d-old leaf; 4) CTV in a completely expanded leaf; and 5) CTV in a mature leaf.

Education Center, University of Florida, Fort Pierce (Lin et al., 2000) and polyclonal antibody PCA 1212 provided by S.M. Garnsey (Lin et al., 2000, 2006) were used. The PCA 1212 was a purified IgG. The MAb 17G11 was an undiluted-cell-culture fluid. Labeled secondary antibody goat anti-mouse Ig $(\mathrm{H}+\mathrm{L})$-alkaline phosphatase conjugate (GAM-AP), purchased from Southern Biotechnology Associates, Inc., Birmingham, Ala, was used to react to CTVspecific MAb 17G11.

Whole-leaf-blotimmunoassay. Fresh leaves taken from the same young shoots or different aged shoots of mexican lime seedlings (Fig. 1) that were infected or uninfected with CTV were stretched on a piece of paper (any kind of clean paper). The cuticle on the under side of the surface of the leaves was carefully removed using a scalpel blade. The scraped lower surface of the leaves was gently pressed on nitrocellulose membrane (Bio-Rad Laboratories, Hercules, Calif.) using a roller and applying a uniform pressure. The blots were detected using the DTBIA procedure (Garnsey et al., 1993; Lin et al., 1990, 2000, 2006). The whole-leaf-blots were air dried for $5 \mathrm{~min}$, incubated with the pre-reaction solution of MAb 17G11 and GAM-AP at 1/1000 dilution for 20 min, rinsed with PBST buffer $(0.15 \mathrm{M}$ sodium chloride, $0.015 \mathrm{M}$ sodium phosphate, $\mathrm{pH}$ 7.0, $0.05 \%$ Tween 20 ) for $5 \mathrm{~min}$, and finally, reacted with NBT-BCIP substrate for 15 to $20 \mathrm{~min}$. The blots were washed in water for 10 to $30 \mathrm{~s}$ to stop the reactions. The positive signal was the development of purple color in the location of veins and the negative was no purple color in the whole-leaf-blots. The experiments were repeated twice with 2 replications per test

Computer scanning imaging. The results of the whole-leaf-blotimmunoassay (WLBIA) of the leaves of infected and uninfected mexican lime plants from above were scanned into a computer with a computer scanner by following the instructions of the computer scanner program. The images were saved as MS Word, Window imaging, or MS PowerPoint files in the computer and printed. The printed images of the results were read for analyzing the distribution and titer of CTV in leaves. The positive signal in the images was the development of red color on the images and the negative was no red color on the images of the whole-leaf blots.

ELISA. Indirect double antibody sandwich (I-DAS) ELISA (Bar-Joseph et al., 1980; Lin et al., 2000; Rocha-Pena and Lee 1991) was carried out with IgG of PCA 1212 as coating antibody and MAb 17G11 as intermediate antibodies and GAM-AP as labeled antibodies to detectCTV in leaves (whole leaves) with different ages from different shoots of the same T-36 infected mexican lime plants as in WLBIA test. Leave samples $(0.5 \mathrm{~g} / \mathrm{sample})$ were extracted with 1X PBST buffer (5 mL/sample). The reaction volume of reagent solutions in each well of the plates was $100 \mu \mathrm{L}$. The substrate for the reactions was $1 \mathrm{mg} \cdot \mathrm{mL}^{-1} \rho$-nitrophenyl phosphate (Sigma) in $0.1 \mathrm{M}$ diethanolamine buffer, $\mathrm{pH}$ 9.8. The absorbance values (415 $\mathrm{nm})$ were determined using a Bio-Rad 3550 reader (Bio-Rad Laboratories). A positive reaction, recorded as "+", was defined as an O.D. $415 \mathrm{~nm}>2.5$ times that of uninfected control (Lin et al., 2000). The ELISA was replicated six times.

\section{Results}

CTV distribution pattern in leaves from different aged shoots. The results of the visualization of the CTV T-36 isolate in the leaves from different-aged shoots of infected mexican lime plants by the whole-leaf-blot immunoassay procedure in combination with a computer scanning imaging technique are shown in Fig. 2A. As can be observed in Fig. 2A, the location of CTV T-36 in the leaves was in the leaf veins. The distribution patterns of CTV $\mathrm{T}-36$ in the mature leaves from different-aged shoots were different (Fig. 2A). CTVT-36 was distributed in all the veins including the main veins and the large and small primary veins in the young leaves from the new shoots of the infected plants. The reaction signals for the virus in these leaves were strong suggesting a high concentration of CTV in the new shoots. In the mature leaves from the medium-aged shoots of the infected plants, the distribution of CTV T-36 was mostly in the main leaf veins and the large primary veins, but seldom in the small primary veins. In the leaves from the old shoots of the infected plants, the distribution of CTV T-36 was only detected in the base of the main veins with very weak signals. The positive signal intensity in the visualized leaf blots of the leaves from different-aged shoots of the infected plants corresponded to the viral titers measured by ELISA of mature leaves sampled from the same shoots of the infected plants as those in the WHBIA test (Fig. 1). The stronger the positive signals for CTV in the leaves of the infected plants in the WHBIA test, the higher the viral titers (ELISA OD ${ }_{415}$ values) of CTV in the leaves of the infected plants in ELISA test (Fig. 2A) and Table 1).

CTV distribution pattern in leaves from the same young shoots. The distribution patterns of CTV T-36 in leaves of different ages from the same new shoots of infected mexican lime plants are shown in Fig. 2B. In new shoots, CTV T-36 was detected in all the leaves regardless of their maturity. However, there were differences in distribution pattern of CTV T-36 among the leaves with different ages from the new shoots. In the youngest leaves, CTV T-36 was mainly distributed in the middle veins of the leaves. In the 3-dayold to completely-expanded leaves, CTV T-36 was distributed in all the veins including the main veins and large and small primary veins. In the mature leaves, CTV T-36 was mostly distributed in the main leaf veins and the larger primary veins; in the small primary veins of the mature leaves, the virus was not detected 
Table 1. Distribution and difference in titer of CTV in leaves (whole leaves) from different shoots tested by indirect double antibody sandwich enzyme-linked-immunosorbent assay (I-DAS ELISA).

\begin{tabular}{lc}
\hline Type of leaves & ELISA $^{z}$ \\
\hline Leaves from new shoots & $1.325 \pm 0.093$ \\
Leaves from medium-aged shoots & $0.956 \pm 0.127$ \\
Leaves from old shoots & $0.674 \pm 0.079$ \\
Leaves from uninfected controls & $0.053 \pm 0.022$
\end{tabular}

${ }^{\mathrm{z}}$ Result of the I-DAS ELISA of the leaves of mexican lime seedlings infected with T-36. Values are averages of $\mathrm{OD}_{415} \pm$ standard deviation based on 6 replications. A positive is defined as an $\mathrm{OD}_{415}>2.5$ times that of uninfected control.

Table 2. Distribution and difference in titer of CTV in leaves (whole leaves) from the same new shoots tested by indirect double antibody sandwich enzyme-linked-immunosorbent assay (I-DAS ELISA).

\begin{tabular}{lc}
\hline Type of leaves & ELISA $^{z}$ \\
\hline Youngest leaves & $1.132 \pm 0.092$ \\
3-d-old leaves & $1.258 \pm 0.081$ \\
5-d-old leaves & $1.536 \pm 0.116$ \\
Completely expanded leaves & $1.292 \pm 0.094$ \\
Mature leaves & $1.046 \pm 0.088$ \\
Uninfected control leaves & $0.056 \pm 0.016$ \\
\hline
\end{tabular}

${ }^{\mathrm{z}}$ Result of the I-DAS ELISA of the leaves of mexican lime seedlings infected with T-36. Values are averages of $\mathrm{OD}_{415} \pm$ standard deviation based on six replications. A positive is defined as an $\mathrm{OD}_{415}>2.5$ times that of uninfected control.

or only detected with very weak signals. The reaction signals of CTV-36 to MAb 17G11 in the 5-d-old and completely-expanded leaves were stronger than that in the 3-d-old leaves and mature leaves. The reaction signals of CTV in the mature leaves were weakest. ELISA results indicated that the 5-d-old and completely expanded leaves had the highest viral titers (ELISAOD ${ }_{415}$ values) and the mature leaves had the lowest viral titers (ELISAOD $_{415}$ values) (Table 2).

\section{Discussion}

These results demonstrate that the distribution pattern of citrus tristeza virus (CTV) in leaves of infected citrus plants can be visualized using a whole-leave-blot immunoassay procedure in combination with computer-scanning imaging. The results also showed that CTV was distributed in all the leaves, from the youngest leaves to the oldest mature leaves of young and old shoots of infected plants. However, the distribution pattern of the virus in leaves varied with age of the leaves and the shoots of the infected plants. The reaction signal in CTV-infected leaves with ages ranging from newly grown to completely expanded, from the young shoots of mexican lime plants, had a high distribution density in most of the leaf veins including the main veins and the large and small primary veins. The leaves from the old shoots, however, had a lower distribution pattern density and reaction signal for CTV. The reaction signal was mostly distributed in the main veins, sometimes also in the large primary veins, but seldom in the small primary veins. In short, CTV incidence in young leaves was higher than that in old leaves in the infected mexican lime plants. This may be caused by the multiplication activity of the virus in the leaves because previous studies (Sasaki et al, 1980) have indicated that CTV multiplies most in actively-dividing cells and there are more actively dividing cells in the young leaves than that in the old leaves. The timing of CTV inoculation is not a significant factor affecting the distribution pattern and incidence of CTV in the leaves in this study because the CTV-infected mexican lime plants used in the study were inoculated with CTV T-36 isolate $>3$ years preceding this study and CTV had been detected in the plants three months later after the inoculation. However, the effects of the initial inoculation tissue and inoculation time on virus distribution are unknown. The effect of the actively dividing and nonactivelydividing cells in the phloem of citrus on the multiplication, accumulation, and degradation of CTV is also unknown.

To our knowledge, the visualization of the distribution pattern of CTV in the leaves of infected citrus plants is reported for the first time. Sasaki et al. (1980) reported the distribution of CTV in tissues of stems and petioles of citrus by fluorescent immunoassay, focusing on the cytopathology of CTV and revealing the distribution of CTV in cells of tissues including protophloem, metaphloem, and meristem adjacent to protophloem of citrus (Sasaki et al., 1980). Lee et al. (1988) reported the distribution of CTV in tissues of citrus by ELISA. However, their investigations emphasized on the distribution of CTV among the flushes of trees, revealing that some flushes were positive for CTV while other flushes were negative for CTV in the same infected citrus plants (Lee et al., 1988). In this study, we investigated the distribution pattern of CTV in individual leaves of citrus. This may be helpful for understanding the movement and mechanism of vector transmission of the virus in infected plants. However, this study only investigated the distribution pattern of CTV T-36 isolate in the leaves of infected mexican lime plants, a susceptible host for this virus isolate. More information about the distribution pattern in leaves of the virus with different isolates and citrus varieties is needed to better understand the functions affecting the distribution, movement, and vector transmission of the virus. The WLBIA should facilitate these studies.

The technique employed in this study is a combination of both the whole-leaf-blot immunoassay (WLBIA) procedure, a modification of direct tissue blot immunoassay (DTBIA) described by Garnsey et al. (1993) and Lin et al. (2000, 2006), and a computer scanning imaging technique. It has several advantages over traditional DTBIA procedures and other immunoassay procedures for certain research purposes, but not for wide-scale survey or diagnosis. It provides the capability to visualize and capture the image of the distribution pattern of CTV in leaves of infected citrus plants. It has the same reliability and sensitivity for detection of CTV as the DTBIA procedure (Lin et al., 2006). However, when making whole-leaf-blots of citrus leaves, care must be taken in removing the cuticle of the low surface of the leaves with a scalpel blade, and then gently pressing the scraped surface to nitrocellulose membranes because the leaves of citrus are fragile, especially the young citrus leaves. Although the distribution pattern of the virus in the leaves is visible in the blots by the assay, this technique does not provide numerical quantification of the virus titer in the tested leaves.

Detecting the distribution pattern of viruses in leaves and other tissues of infected plants is important because we need to understand the distribution and titer of viruses in the tissues of infected plants in many studies. Examples of such studies include considering a mild strain to cross protect against severe strains of viruses, expressing a transgenic gene to obtain resistance to viruses, monitoring the movement of viruses in infected plants, choosing the source plant for aphid transmission, and selecting tissues for virus purification. Hopefully, whole-leaf-blot immunoassay in combination with computer scanning imaging will be useful for other viruses as well as CTV.

\section{Literature cited}

Bar-Joseph, M., S.M. Garnsey, D. Gonsalves, and D.E. Purcifull. 1980. Detection of citrus tristeza virus. I. Enzyme-linked immunosorbent assay (ELISA) and SDS-immunodiffusion methods, p. 1-8. In: Proc. 8th Conf. IOCV. IOCV, Riverside.

Brlansky, R.H. and R.F. Lee. 1988. In Situ immunofluorescence for the detection of Citrus tristeza vireus inclusion bodies. Plant Dis. 72:1039-1041.

Brlansky, R.H. and R.F. Lee. 1990. Number of inclusion bodies produced by mild and severe strains of Citrus tristeza virus in seven citrus host. Plant Dis. 74:297-299.

Garnsey, S.M., R.G.Christie, and K.S. Derrick. 1980. Detection of Citrus tristeza virus. II. Light and electron microdcopy of inclusions and viral particles, p. 9-16. In: E.C. Calavan, S.M. Garnsey, and L.W. Timmer (eds.). Proc. Conf. Intl. Prgan. Citrus Virol. 8th ed. IOCV, Riverside.

Garnsey, S.M., T.A. Permar, M. Cambra, and C.T. Henderson. 1993. Direct tissueblotimmunoassay (DTBIA) for detection of citrus tristeza virus (CTV), p. 39-50. In: Proc. 12th Conf. IOCV. IOCV, Riverside.

Ghorbel, R., C. Lopez, C. Fagoga, P. Moreno, L. Navarro, R. Flores, and L. Pena. 2001. Transgenic citrus plant expressing the Citrus tristeza virus $\mathrm{p} 23$ protein exhibit viral-like symptoms. Mol. Plant Pathol. 2(1):27-36.

Huang, Z., P.A. Rundell, X. Guan, and C.A. Powell. 2004. Detection and isolate differentiation of Citrus tristeza virus in infected field trees based on reverse transcription-polymerase chain reaction. Plant Dis. 88:625-629.

Hung, T.H., M.L. Wu, and H.J. Su. 2000. A rapid method based on the one-step reverse transcriptase-polymerase chain reaction (RT-PCR) technique for detection of different strains of Citrus tristeza virus. J. Phytopathol.148(78):469-475

Kitajima, E.W. and A.S. Costa. 1968. Electron microscopy of the tristeza virus in citrus leaf tissues, p. 59-64. In: J.F. Childs (ed.). Proc. Conf. Intl. Organ. Citrus Virol. 4th ed. Univ. Fla. Press, Gainesville.

Kitajima, E.W., G.W. Muller, and A.S. Costa. 1974. Electron microscopy of tristeza-infected Passiflora gracitis (Jacq), p. 79-82. In: L.G. 
Weathers and M. Cohen (eds.). Proc. Conf. Intl. Organ. Citrus Virol. 6th ed. Univ. Calif., Div. Agr. Sci., Richmond.

Labonne, G., J.B. Quiot, M. Yvon, and L. QuiotDouine. 1997. Immunoprinting: A quick and reliable method to measure the efficiency of plant as virus source for aphids in field epidemiology. J. Plant Pathol. 79:135-141.

Lee, R.F., S.M. Garnsey, L.J. Marais, J.N. Moll, and C.O. Youtsey. 1988. Distribution of Citrus tristeza virus in Grapefruit and sweet orange in Florida and South Africa, p. 33-38. In: Proc. 10th Conf. IOCV. IOCV, Riverside, Calif.

Lin, Y., P.A. Rundell, and C.A. Powell. 2002. In situ immunoassay (ISIA) of field grapefruit trees inoculated with mild isolates of Citrus tristeza virus indicates mixed infections with severe isolates. Plant Dis. 86:458-461

Lin, Y., P.A. Rundell, L. Xie, and C.A. Powell. 2000. In situ immunoassay for detection of Citrus tristeza virus. Plant Dis. 84:937-940.

Lin, Y., P.A. Rundell, L. Xie, and C.A. Powell. 2006. Pre-reaction of Citrus tristeza virus (CTV) specific antibodies and labeled secondary antibodies in solutions enables direct tissue blot immunoassay to detect CTV within 1 hour.
Plant Dis. (in press).

Lin, N.S., Y.H. Hsu, and H.T. Hsu. 1990. Immunological detection of plant viruses and mycolasmalike organism by direct tissue blotting on nitrocellulose membranes. Phytopathology 80:824-828.

Mas, P., and V. Pallas. 1995. Non-isotopic tissueprinting hybridization: a new technique to study long-distance plant virus movement. J. Virol. Meth. 52:317-326.

Niblett, C.L., H. Gene, B. Cevik, S.Halbert, L. Brown, G. Nolaseco, B. Bonacalza, K.L. Manjunath, V.J. Febres, H.R. Pappu,, and R.F. Lee. 2000. Progress on strain differentiation of Citrus tristeza virus and its application to the epidemiology of citrus tristeza disease. Virus Res. 71 (1-2):97-106.

Polston, J.E., P. Bubrick, and T.M. Perring. 1991. Detection of plant virus coast proteins on wholeleaf blots. Anal. Biochem. 196(2):267-270.

Rocha-Pena, M. and R.F. Lee. 1991. Serological technique for detection of Citrus tristeza virus. J. Virol. Methods 34:311-331.

Rocha-Pena, M.A., R.F. Lee, and C.L. Niblett. 1991. Development of a dot-immunobinding assay for detection of Citrus tristeza virus. J. Virol. Methods 34:297-309.
Sambade, A., S. Martin, A. Olmos, M.L. Garcia, M. Cambra, O. Grau, J. Guerri, and O. Moreno. 2000. A fast one-step reverse transcription and polymerase chain reaction (RT-PCR) amplification procedure providing highly specific complementary DNA from plant virus RNA. J. Virol. Meth. 87(1-2):25-28.

Sasaki, A., T. Tsuchizaki, and Y. Saito. 1980. Distribution of Citrus tristeza virus antigen in citrus tissues, p. 17-19. In:E.C. Calavan, S.M. Garnsey, and L.W. Timmer(eds.). Proc. Conf. Intel. Organ. Citrus Virol. 8th ed. IOCV, Riverside.

Schneider, H. 1959. The anatomy of tristeza virusinfected citrus, p. 73-84. In: J.M. Wallace (ed.) Citrus virus diseases. Univ. Calif., Berkeley.

Schneider, H. and P.J. Sasaki. 1972. Ultrastructual studies of chromatic cells in tristeza-diseased lime, p. 222-228. In: W.C. Price (ed.). Proc. Conf. Intl. Organ. Citrus Virol. 5th ed. Univ. Fla. Press, Gainesville.

Zhou, C.L.E., E.D. Ammar, H. Sheta, S. Kelley, M. Polek, and D.E. Ullman. 2002. Citrus tristeza virus ultrastructure and associated cytopathology in Citrus sinensis and Citrus aurantifolia. Can. J. Plant Bot. 80 (5):512-525. 